Section Editor

Mitchell S.V. Elkind, MD, MS

Mystery Case:

\title{
Superior oblique myokymia due to vascular compression of the trochlear nerve
}

回

SeokHoon Kang, MD Ji-Soo Kim, MD, PhD Jeong-Min Hwang, MD, $\mathrm{PhD}$

Byung Se Choi, MD Jae-Hyoung Kim, MD,

$\mathrm{PhD}$

Correspondence to

Dr. J.-S. Kim:

jisookim@snu.ac.kr
Supplemental data at www.neurology.org

\section{Figure High-resolution MRIs}

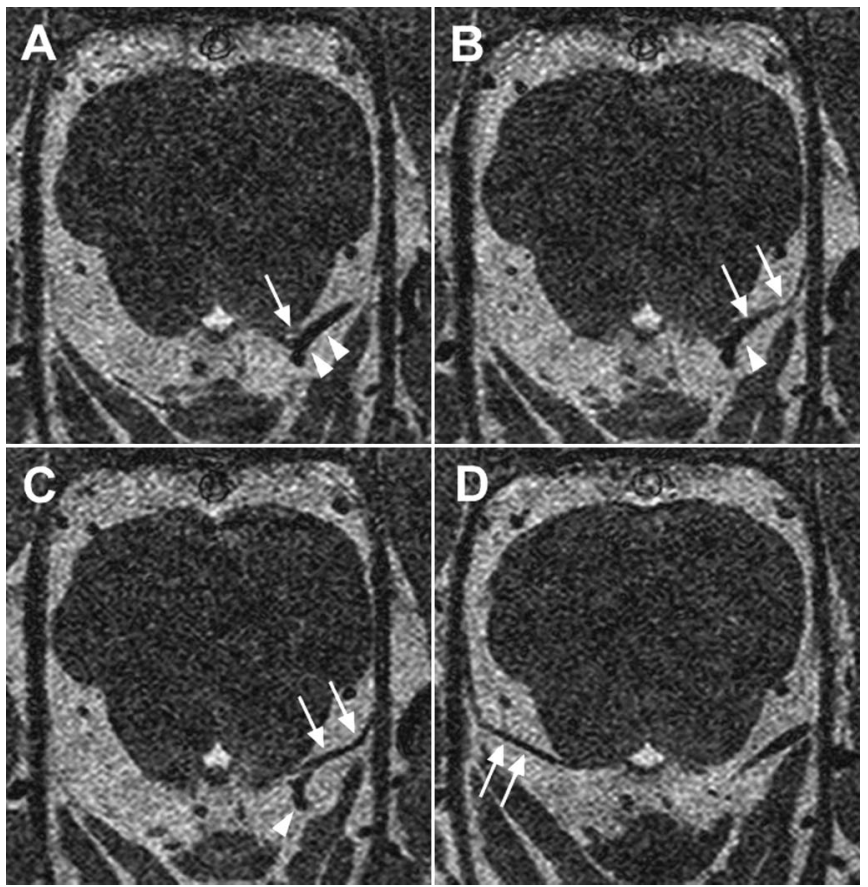

(A-C) Three-dimensional balanced turbo field echo images with a voxel size of $0.25 \times 0.25 \times 0.25 \mathrm{~mm}$ thickness reveal the left trochlear nerve (arrows) compressed by the left superior cerebellar artery (arrowheads) in the quadrigeminal cistern. (D) In contrast, right trochlear nerve passes through the cistern without a contact with vascular structures.

A 37-year-old man with episodic oscillopsia for 3 months showed intermittent torsional-vertical oscillation of the left eye (video on the Neurology ${ }^{\circledR}$ Web site at www.neurology.org). MRI revealed an attachment between left trochlear nerve and left superior cerebellar artery in the quadrigeminal cistern (figure). Gabapentin $600 \mathrm{mg}$ twice a day ameliorated the ocular oscillation and oscillopsia.

Superior oblique myokymia (SOM) causes monocular oscillopsia or torsional diplopia due to involuntary contractions of the superior oblique muscle. ${ }^{1} \mathrm{SOM}$ may develop in association with pathologies involving the brainstem or vascular compression of the trochlear nerve in the subarachnoid space. ${ }^{2}$ In refractory patients with SOM, medications or microvascular decompression may be considered.

\section{AUTHOR CONTRIBUTIONS}

Dr. Kang wrote the manuscript and analyzed and interpreted the data. Dr. J.-S. Kim conducted the design and conceptualization of the study, interpretation of the data, and drafting and revising the manuscript. Drs. Choi, Hwang, and J.-H. Kim analyzed and interpreted the data and revised the manuscript.

\section{REFERENCES}

1. Hoyt WF, Keane JR. Superior oblique myokymia: report and discussion on five cases of benign intermittent uniocular microtremor. Arch Ophthalmol 1970;84:461-467.

2. Hashimoto M, Ohtsuka K, Hoyt WF. Vascular compression as a cause of superior oblique myokymia disclosed by

From the Department of Neurology (S.K.), Kangwon National University Hospital, Chuncheon, Gangwon; and Departments of Neurology (J.-S.K.), Ophthalmology (J.-M.H.), and Radiology (B.S.C., J.-H.K.), Seoul National University College of Medicine, Seoul National University Bundang Hospital, Seongnam, Gyeonggi, South Korea.

Study funding: No targeted funding reported.

The authors report no disclosures relevant to the manuscript. Go to Neurology.org for full disclosures. 
thin-slice magnetic resonance imaging. Am J Ophthalmol 2001;131:676-677.

MYSTERY CASE RESPONSES The Mystery Case series was initiated by the Neurology Resident \& Fellow Section to develop the clinical reasoning skills of trainees. Residency programs, medical student preceptors, and individuals were invited to use this Mystery Case as an education tool. Responses were solicited through a group e-mail sent to the American Academy of Neurology Consortium of Neurology Residents and Fellows and through social media. All the answers that we received came from individual residents rather than groups. Most of the respondents (83\%) correctly identified the left superior oblique myokymia illustrated in the video and considered as etiology a vascular compression of the proximal cisternal segment of the left trochlear nerve by the left superior cerebellar artery. They also indicated the medical and surgical management options for this condition.

The most complete answer came from Dr. Jithin George (Oxford, UK). In his response, he pointed out that, based on retrospective data, carbamazepine is the most effective medical treatment, while gabapentin, $\beta$-blockers, phenytoin, sodium valproate, and baclofen were reported to have various benefits. ${ }^{1,2}$ For medically refractory cases, microvascular decompression of the trochlear nerve, superior oblique tenotomy or tenectomy, and inferior oblique myectomy are surgical treatment options available. ${ }^{1,3}$ Dr. Luca Bello (Padova, Italy) and Dr. Damien Biotti (Lyon, France) also provided thoughtful and comprehensive answers.

Dragos A. Nita, MD, PhD

The Hospital for Sick Children, University of Toronto, Toronto, Canada

1. Brazis PW, Miller NR, Henderer JD, Lee AG. The natural history and results of treatment of superior oblique myokymia. Arch Ophthalmol 1994;112:1063-1067.

2. Williams PE, Purvin VA, Kawasaki A. Superior oblique myokymia: efficacy of medical treatment. J AAPOS 2007;11:254-257.

3. Agarwal S, Kushner BJ. Results of extraocular muscle surgery for superior oblique myokymia. J AAPOS 2009;13:472-476. 


\section{Neurology}

\section{Mystery Case:Superior oblique myokymia due to vascular compression of the trochlear nerve}

SeokHoon Kang, Ji-Soo Kim, Jeong-Min Hwang, et al.

Neurology 2013;80;e134-e135

DOI 10.1212/WNL.0b013e318289706f

\section{This information is current as of March 25, 2013}

\section{Updated Information \&}

Services

Supplementary Material

References

Subspecialty Collections

Permissions \& Licensing

Reprints including high resolution figures, can be found at: http://n.neurology.org/content/80/13/e134.full

Supplementary material can be found at: http://n.neurology.org/content/suppl/2013/03/24/80.13.e134.DC1

This article cites 5 articles, 0 of which you can access for free at: http://n.neurology.org/content/80/13/e134.full\#ref-list-1

This article, along with others on similar topics, appears in the following collection(s):

Nystagmus

http://n.neurology.org/cgi/collection/nystagmus

Oscillopsia

http://n.neurology.org/cgi/collection/oscillopsia

Information about reproducing this article in parts (figures,tables) or in its entirety can be found online at:

http://www.neurology.org/about/about_the_journal\#permissions

Information about ordering reprints can be found online:

http://n.neurology.org/subscribers/advertise

Neurology ${ }^{\circledR}$ is the official journal of the American Academy of Neurology. Published continuously since 1951, it is now a weekly with 48 issues per year. Copyright @ 2013 American Academy of Neurology. All rights reserved. Print ISSN: 0028-3878. Online ISSN: 1526-632X.

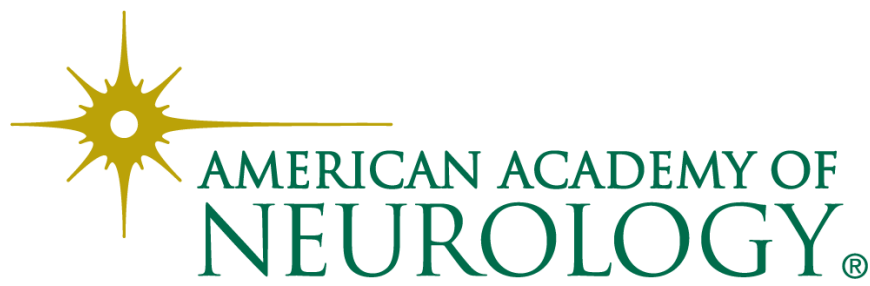

